\title{
AL-FARABI'S LEGACY IN STUDIES OF AKZHAN ZHAKSYBEKOVICH MASHANOV (AL-MASHANI)
}

\author{
${ }^{1}$ Aidos Makulbekov, ${ }^{2}$ Saduov Asylkhan \\ 1,2aidossozak@mail.ru, ${ }^{2}$ saduov78@mail.ru \\ L.N. Gumilyov Eurasian National University \\ (Nur-Sultan, Kazakhstan)
}

\author{
${ }^{1}$ Макулбеков Айдос Толебекулы, ${ }^{2}$ Садуов Асилхан Жумабаевич \\ 1,2aidossozak@mail.ru, ${ }^{2}$ saduov78@mail.ru \\ Евразийский национальный университет имени Л.Н. Гумилева, \\ (Нур-Султан, Казахстан)
}

\begin{abstract}
Absrtact. The article covers the contribution of Akzhan Zhaksybekovich Mashanov, Doctor of Geological and Mineralogical Sciences, Professor, corresponding member of the Academy of Sciences of the Kazakh SSR, honored scientist of Kazakhstan, in the field of studying the scientific legacy of Abû-Nasr Muhammad ibn Muhammad A-Farabi. A.Zh. Mashanov was the first to explore the writings of great Al-Farabi. Mashanov's internal memo as of 15.11. 1960 addressed to the President of the Academy of Sciences of the Kazakh SSR, K.I. Satpayev, on the necessity to proceed with the research of the scientific legacy of Al-Farabi gave a start to the development of Farabi-studies in Kazakhstan.

Akzhan Zhaksybekovich not only proved to the global community that the birthplace of the Second Teacher is the city of Otrar, but also discovered the burial site of the prominent ancestor at the Bab-as-Sagir cemetery in Damask. The scientist could provide solid arguments and persuade academic circles of the USSR on the need to start studying Al-Farabi's legacy in Kazakhstan, in the native land of the genius thinker. Thanks to his efforts, in 1975, the city of Alma-Ata hosted the international scientific conference dedicated to the $1100^{\text {th }}$ anniversary since the birth of Al-Farabi.
\end{abstract}

Key words: A.Zh.Mashanov, Abu Nasr Muhammad Ibn Muhammad AlFarabi, Farabi-studies, Otrar, Bab-as-Sagir cemetery, Kitab Al-Musiki Al Kabir.

\section{Introduction}

The Seven Facets of the Great Steppe program-embedded article by the Leader of the Nation, Nursultan Nazarbayev, has become a centerpiece of the strategy of spiritual development of the Kazakhstani society and national self-consciousness. Mahabbat Kozybayeva, PhD, academic secretary of Valikhanov Institute of History and Ethnology named after, gave a comprehensive and precise description of the role of that epoch-making document by saying that «Kazakh- 
stan faces another stage of the spiritual modernization aimed at forming a highly-spiritual person with a vividly shaped patriotic component. Knowing his roots and enjoying the many-century wisdom of his ancestors, a person feels much more confident and makes progress towards a better future. Thoughts of Elbasy Nursultan Nazarbayev are filled with noble spiritual tutoring contents, and he acts as a teacher, especially to young minds, inspiring them on lofty goals and ambitious path. From this perspective, Elbasy's new article 'Seven Facets of the Great Steppe' is laced with the truly deep philosophical meaning".

In her view, the said article continues the idea of the integrated modernization of the social consciousness. In his program-based article 'Course Towards the Future: Modernization of Kazakhstan's Identity', Elbasy, having considered peculiarities of the national consciousness and regional division of the historical entirety: "It is useful to know and take pride in the history of your region. But one should never forget about the more important things - that he or she belongs to the great nation". Later, in his book 'The Era of Independence', the First President of Kazakhstan explained his beliefs that processes of political and economical modernization should derive from the renewal of the social consciousness. Yet, on the other side, the fundamental covenant of the new-age modernization resides in the preservation of own culture and own national code. This is the exact reason why the "new modernization is a platform connecting horizons of the nation's past, present, and future'.

"Big things are better seen from a distance; and, as time has shown, certain structuring as well as defining approaches to the exploration of the subject of study, developing a unique model of the nomad civilization, and determining our own place within the global historical context, is both necessary and very relevant. The article of the President continues studying the authentic history of the Great Steppe. Its author summons to realize and accept our history in all its versatility and multidimensionality ... understand our role in global history, based on strict scientific facts", Mahabbat Kozybayeva said. Indeed, the Great Steppe, rich in its authentic history, blessed the world with many passionarians and repeatedly gave an impetus to the progressive evolution of the entire world civilization. The idea of forming a national so-called Golden Pool of the names of historical personalities and their deeds in pursuit of the establishment and prosperity of modern Kazakhstan and overall Steppe civilization belongs to the Leader of the Nation, Nursultan Nazarbayev, who set it forth in his program-embedded article 'Seven Facets of the Great Steppe'. Speaking of achievements of our outstanding ancestors, Nursultan Abishevich said: "The Great Steppe produced an entire assemblage of the brilliant men, including such titanic characters as Al-Farabi and Yasawi, Kul-Tigin and Beibars, Tauke and Abylai, Kenessary and Abai, and many others".

As scientists believe, 'many others' here means tens, if not hundreds, of thousands of personalities of various epochs: rulers, military leaders, thinkers, and poets, whose heroic deeds, texts, and endeavors created the historical capital of our Motherland, glorifying it for centuries throughout the global history.

According to Ludmila Makarenko, the author of the article 'Great Names of the Many-Century History', the concept of the encyclopedia of prominent personalities 
is far not the first suggestion within the framework of new initiatives to preserve the past of our people. Projects named in the article 'Seven Facets of the Great Steppe' logically continue the Rukhani Zhangyru (Spiritual Revival) program. The matter of strengthening our historical memory, including on returning the names of the great characters of various times to the Kazakh nation, was voiced in Madeni Mura (Cultural Inheritance) program started as far as in 2003.

It is hard to overestimate the contribution of science into that process: in-depth academic studies were conducted, articles and monographs prepared, while scientific discoveries allowed reconsidering a number of paradigms. It is time to adapt our ancestors' legacy to the modern reality and use it as one of the pillars of growth, and our historical experience will serve as the foundation for renewing the social consciousness.

The world science is well familiar with the texts of the Second Teacher. He wrote numerous tractates in the field of history, philosophy, cultural science, astronomy, music, and other areas. It is proved that Al-Farabi's personality development had taken place within the territory of Kazakhstan.

In the context of the modern reality, the role and the significance of science as the major driver for implementing the Strategic Development Program of our Republic - Kazakhstan-2050 continue their extensive growth. To date, national science is mastered on the solid basement, having been created by the galaxy of the outstanding scientists led by Kanysh Imantayevich Satpayev. Intellectual, scientific and education, and as well as cultural resources are the best heritage that independent Kazakhstan gained from the Soviet era.

\section{Methodology}

In research work, historical and logical, comparative, pacisological, content analysis, scientific analysis methods such as epistolar are used. Which provides for a combination of formal-logical and historical approaches through the prism of a culturology. In addition, this work is based on archival data of al-Farabi's legacy and AlMashani's research work.

\section{The Leader of Farabi Scholars in Kazakhstan}

According to the author of the article 'Al-Mashani, a Distinguished Kazakh Scholar, Writer, Teacher', Altayev A.Sh., though by certain parameters of social and economic development we are still striving to enter the top 30 most competitive states, if you look at our achievements in terms of separate areas of science and culture, Kazakhstan can be justly put in one row with the most developed countries. And this is the merit of our remarkable scientists who spent all their lives to the devoted servicing to their Motherland, and Akzhan Zhaksybekuly Mashanov or Al-Mashani in the modern transcription (1906-1997) can be undoubtedly named among them.

As brilliant thinkers of the medieval East, Akzhan Mashanov can be quite literally considered to be a person of encyclopedic knowledge. His scientific interests touched upon all fields of both natural and social sciences. 
Akzhan Mashanov was known to have a truly all-round knowledge and extensive scientific erudition; he could both catch every piece of new information and successfully use it in his scientific and pedagogic activities.

As written in the introduction to many-volume 'Al-Farabi and Modern Science' by Akzhan al-Mashani, re-issued in 2007, Akzhan Zhaksybekuly Mashanov was one of the first graduates of the Kazakh National Technical University (KazNTU) named after K.I.Satpayev and its first post-graduate student. He spent over 60 years of his professional activities to the uninterrupted preparation of engineering specialists for the Republic, combining them with multi-targeted studies, whose key accent was made at Al-Farabi's legacy. In fact, in Central Asia, Al-Mashani was the pioneer and the founder of the studies aimed at studying transactions of our amazing ancestor, having devoted over fifty years of his life to that goal until his death. It bears mentioning that such gigantic efforts of academic Mashani facilitated development of spiritual values of his nation and served as a significant contribution of the Kazakh people into the world civilization in the prism of studying Al-Farabi's life and work.

The destiny of high-profile historical personalities is never limited by the time frame of their life and always bears their moral message to future generations. "It is impossible to understand any epoch, if you have no understanding of its great people, since their life stories allow us seeing the thread of the history and absorb its spirit", Elbasy N.A.Nazarbayev pointed out.

Studies of Al-Farabi's legacy in Kazakhstan are associated, above all, with the name of Akzhan Zhaksybekovich Mashanov, a person of encyclopedic knowledge, an exceptional scientist. He was the pioneer who discovered the name of Abu Nasr Al-Farabi to millions of Kazakhstani people. After Mashanov's publications, not only Al-Farabi but also the city of Otrar, the birthplace of the great medieval thinker, became a point of growing interest. A lot of Mashanov's writings on the life and legacy of Al-Farabi were translated into many languages of the globe.

For more than 50 years, Mashani steadily and scrupulously explored tractates of the phenomenal philosopher. His concept of Farabi-studies, where Al-Farabi plays an honorable role of the Second Teacher in the world history, is, so to say, an axiom that needs no proving. Yet, if you ask 'What are findings of the great ancestor in astronomy, music, and geometry, so great that he is worthy being named the Second Teacher?', it is hardly possible that anyone from scientists who deal with Farabi-studies can give a truly exhaustive answer thereto. And if you ask the question beyond academic circles, sometimes it may appear that young people know Al-Farabi only by his image on our tenge. This is why it is absolutely necessary to foster propagating the legacy of our well-deserved countryman. That said, taking into consideration that Kazakhstan's community is familiar with solitary writings of the scientist (and such awareness has been formed during the last 3040 years) only, we should bear in mind that what is known represents just a drop in the ocean of his scholarly texts that have an immense informative and educational meaning and can be availed to his descendants. So are we to be satisfied with what we have?! In short, Farabi-studies remain an aspect pending its further development.

For the first time, Akzhan Zhaksybekovich heard the name of Al-Farabi in 1943, during the lecture 'On Great Thinkers of Central Asia' conducted by Ernest Yarom- 
irovich Kolman, a Soviet Marxist- philosopher and mathematician [1] Being a patriot and a tireless truth-hunter, Akzhan Zhaksybekovich was one of the first representatives of the Kazakhstani science who paid attention to studying the legacy of Abû-Nasr Muhammad ibn Muhammad A-Farabi. Remembering that moment, he wrote: "Does anyone prohibit us from studying the scientific legacy of Al-Farabi? Is it not a direct and honor commitment of the scholars of Kazakhstan, his homeland? It is our duty to our people and to the memory of one of its greatest sons. So, I have set a goal for myself to give a start to studying Farabi 's legacy. It was in the year of 1956..." [2].

As Akzhan Zhaksybekovich noted, Al-Farabi had been known in Kazakhstan for quite a while, "but apart from that knowledge we had none of his writings. Within the USSR we could find only separate extracts in the field of philosophy" [1, $5 \mathrm{p}$.]. In this regard, the scientist started an active search of the texts of the medieval sage: he worked in archives and libraries of Kazakhstan, Caucasus, Russia, Lithuania; maintained an intensive correspondence with the libraries of the Jagiellonian University (Krakow, Poland), Royal Monastery of San Lorenzo de El Escorial (Madrid, Spain), Uppsala University (Uppsala, Sweden), Lebanese National Library (Beirut, Lebanon), and other hubs of scientific and historical knowledge. Akzhan Zhaksybekovich not only established relations with the leading world libraries, but also managed to receive copies of microfilms about Al-Farabi's tractates. So, in autumn of 1962, he obtained a copy of Al-Farabi's tract 'Kitab al-musiki al-kabir' ('The Great Book of Music') from the library of Leiden University (Leiden, Netherlands). In his script "Following the Footsteps of Al-Farabi", Akzhan Zhaksybekovich mentioned that event: "One of first persons to study the book was Akhmet Zhubanov, the honored artist of the Kazakh SSR, academic of the Academy of Science of the Kazakh SSR, composer and music expert".

Looking through the Al-Farabi's 'The Great Book of Music' and scrutinizing Al-Farabi's drawings and pictures of musical instruments, Mashanov felt ineffable joy. At some point one of the pictures captured his attention. It showed a divine figure, the Venus with the lute, playing music. Having read the note in Arabian under the picture, he said "Our ignorant detractors state that such images as well as such understanding of music had been prohibited in the East ... I gave him several photo shots of Al-Farabi's musical instruments. Some days later, he published a large article in the Sotsialistyk Kazakhstan newspaper ('Socialistic Kazakhstan') on that major event for the musical life of the Republic" [1,65 p.].

The library of Uppsala University provided the scientist with a microfilm on Al-Farabi's mathematical tract, while the library of Bratislava University sent a copy of Al-Farabi's scripts on logic and philosophy. It stands to mention that all those tracts had not been published before. Thus, as a result of those impressive search efforts, Kazakhstan became an owner of the original collection of Al-Farabi's texts, "now we could feel confident to proclaim to the world that the homeland of the 'Eastern Aristotle'serves as the center of exploring his scientific legacy [1, 66 p.].

From 1958 through 1968, Akzhan Mashanov took a series of trips along Al-Farabi's trail, from the place of his birth to his burial site. Mashani visited Arystan-Bab mausoleum in Otrar (see Photo 1 'A.Zh.Mashanov next to Arystan-Bab mausoleum') and Bab-as-Sagir cemetery in Damask, Syria (see Photo 2 'A.Zh.Mashanov at Bab- 
as-Sagir cemetery in Damask'). The explorer noted that prior to 1968 "neither Arystan-Bab, nor Bab-as-Sagir had been fixed anywhere in the world in the context of the Modern History. I was the first one to photograph both those places, created by the birth and death of the great thinker, and publish materials thereon" [1, 5 p.].

When recalling his trip to Damask, Akzhan Zhaksybekovich described his state of mind at the moment when he had found the burial place of Al-Farabi with the following heart-pounding words: "I couldn't help crying. I put a handful of the earth from Al-Farabi's grave into a handkerchief and devoted a surah from the Quran to him " [3].

There, in Damask, standing near Al-Farabi's grave, Akzhan Mashanov expressed his emotions in a poem:

"You who connected Turkestan and ancient Sham forever,

Here I am, your progeny,

Standing at the grave of the one whose wisdom is deeper than a river.

Who of all Turks, Persians, or Arabs doesn't know your name?!

And others will know when they look at the History's pedestal rock!

I searched your grave for many months;

I came here from your Motherland.

I took just a handful of earth from your grave to be my talisman.

Oh, the Mosque - cupolas of Magaui! Dust of centuries... What witnessed you?!

The place of sacred-Dar as-Salam.

Ninety branches come together here; it is a crossroad of many paths.

Here peoples perceive history, and here the Fate rested your soul".

(Unofficial translation)

23.09.1968, Damask

Photo 1. A.Zh.Mashanov next to Arystan-Bab mausoleum

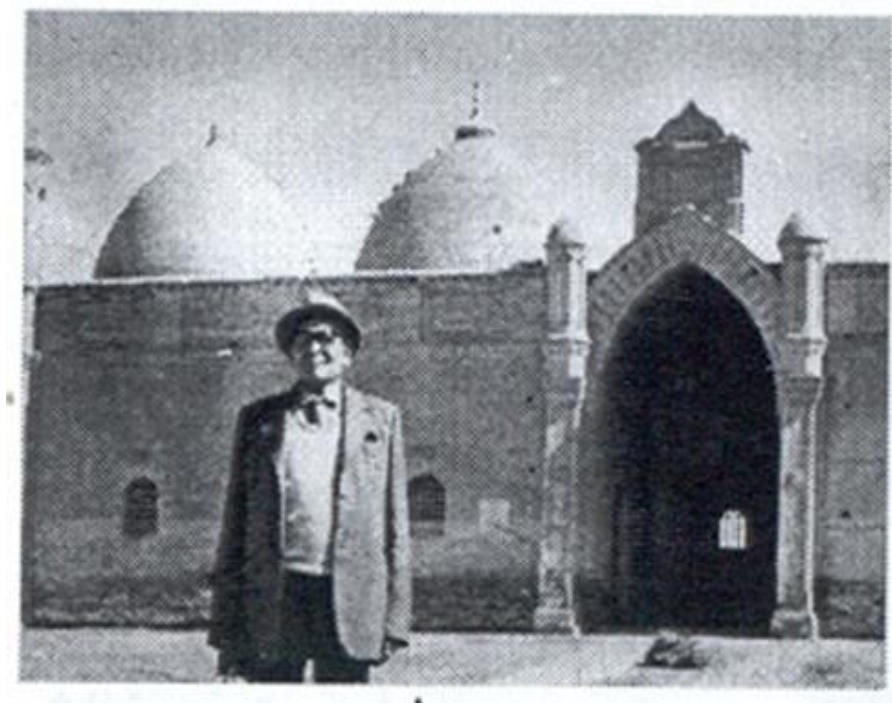


Photo 2. A.Zh. Mashanov at Bab-as-Sagir cemetery in Damask

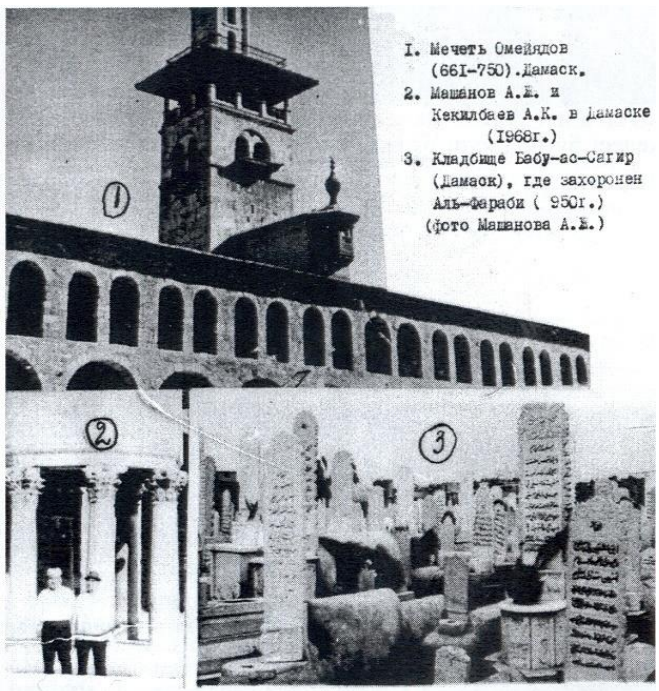

Hence, we can make a conclusion that Akzhan Zhaksybekovich was the first scientist out of Kazakhstan and entire ex-USSR territory who had not only found the place of burial of the outstanding scholar and philosopher of the Middle Times, AbûNasr Muhammad ibn Muhammad A-Farabi, but had also proved that the native land of the medieval sage was the city of Otrar as he was able to provide evidences in connection therewith. The Second Teacher was born in the Kazakh steppe. To that extent, Sh. A. Abdraman said: "That was a stroke on the widely spread Communistic assumption that nomads had reached civilization only during the Soviet Union times" [4].

As from 1960, Akzhan Mashanov carried out an active propaganda of Al-Farabi's texts and started engaging people for implementing Farabi-studies in Kazakhstan. In November of that year, A.Mashanov prepared an internal memo addressed to K.I.Satpayev on the necessity to conduct systemic research of the scientific legacy of Al-Farabi. The internal memo was endorsed by K.Satpayev as "Agreed. Approved for implementation" on 15.11.1960 г. [1, 4 p.]. Positive resolution was received. Yet, its implementation wasn't that smooth. One of the reasons, inter alia, was the unexpected death of Kanysh Satpayev. A. Mashanov took that news heavily; he couldn't recover from that blow for quite a long. At first, the new President of the Academy of Sciences of the Kazakh SSR, Shafik Chokin, wanted to accomplish his predecessor's initiative and include research activities in the Academy's work plan. However, due to certain circumstances he was not able to do it. Only when Shakhmardan Yesenovich Yesenov became the head the Academy of Sciences of the Kazakh SSR, studies of the scientific legacy of Abû-Nasr Muhammad ibn Muhammad A-Farabi started.

In 1968-69, the Academy of Sciences of the Kazakh SSR included Farabi-studies in its work plan. In his memoirs, Akzhan Zhaksybekovich wrote that "up till now, I had been studying Al-Farabi's scientific legacy on my own initiative and at my own 
expense for ten years. It was my second risk and sacrifice for the sake of science after my work on geomechanics" [5]. As Akzhan Zhaksybekovich said: "that time I received a response to my solicitation only from a very few people" [1, 6 p.], namely, from A.Kubesov (mathematician) and I.M. Khairullov (philosopher). Among leading Orientalists of the USSR, who provided a lot of help to Mashanov, we can name academics B.G.Gafurov, B.M.Kedrov, and P.N.Fedoseyev, and professors E.Ya.Kolman, A.P.Yushkevich, and B.A.Rozenfeld [1, 7 p.]. Due to the support of those scholars, Akzhan Zhaksybekovich took an active part in many scientific conferences and symposiums of the international, USSR-, and Republican level. That was the dawn of the later formed separate direction of the Kazakhstani science - Farabi-studies, whose center was hosted in the Academy of Sciences of the Kazakh SSR [2, 167 p.]. Speaking of the development of Farabi-studies in Kazakhstan, G.K. Kurmangaliyeva noted: "Development of Farabi-studies in Kazakhstan started thanks to the efforts of A. AlMashani, A.Kh.Kasymzhanov, A.K.Kubesov, and others, and also due to the support of the management of the Academy of Sciences" [2, p.167 p.].

In 1968, the Institute of Philosophy and Law under the Academy of Sciences of the Kazakh SSR launched research activities on exploring the scientific legacy of Al-Farabi. The program 'Al-Farabi's Scientific Legacy' to be implemented during 1968-1970 was assigned to A.Mashanov, A.Kubesov and A.Kasymzhanov [6]. The key objective of the program resided in extended exploring Al-Farabi's legacy, bringing together scripts and texts by Al-Farabi, translating the sage's tractates into Russian, and publishing collected books dedicated to the analysis of Al-Farabi's writings in the Kazakh and Russian languages.

\section{World Scientific Forum Dedicated to the "Second Aristotle".}

In 1971, results of the research dedicated to Al-Farabi conducted by a group of Kazakhstani scientists under the leadership of A.Mashanov were presented at the $13^{\text {th }}$ UNESCO Congress in Moscow. There and then a historical decision on organizing a scientific conference in the honor of the $1100^{\text {th }}$ Al-Farabi's anniversary in Kazakhstan was taken. Thus, the World Scientific Forum under the theme of Second Aristotle took place on September 8-13, 1975. Events under the auspices of the Forum started in Moscow and finished at the scientist's Motherland - in the city of Alma-Ata, Kazakhstan. That was the first public arrangement and first acknowledgement of Al-Farabi at the international stage [7]. By that time, Al-Mashani's 32 scientific papers on the legacy of Al-Farabi, including two monographs and historic novel 'Al-Farabi', had been published. The latter was the first book in the Kazakh literature dedicated to the global thinker.

It should be emphasized that when the scholars of Kazakhstan raised an issue of the necessity to explore Al-Farabi's scientific legacy and posed a question of organizing his jubilee festivities on the $1100^{\text {th }}$ anniversary of his birth, "some of our fraternal peoples (Tadjiks and Uzbeks) started pretending to claim Al-Farabi's legacy" [1, 69 p.]. Uzbek Orientalists directly insisted that the center of studies of the scientific legacy of Al-Farabi should be the city of Tashkent, but not Alma-Ata, giving a number of reasons as follows: 
1. Al-Farabi was a scholar of the entire Central Asian region, but not a Kazakh, since the Kazakh nation hadn't formed yet at that time.

2. The place of his birth is near Tashkent, while Alma-Ata is much farther.

3. Uzbekistan has already established a special Institute of Eastern studies, having skilled personnel to explore Al-Farabi's scientific legacy, whereas Kazakhstan cannot boast having the one as well as its own group of relevant translators.

All above-listed reasons seemed to be quite justified, and yet, the arguments of the Kazakh side turned out to prevail:

1. According to the existing tradition, the principal hub of exploring the legacy of a scholar is typically the country considered to be his or her homeland.

2. Based on the same grounds and the same principle, Kazakhstan has a right to consider itself to be a lawful inheritor of Al-Farabi's legacy as the latter was born within the territory of Kazakhstan. In addition, Kazakhstani scholars had started studying Al-Farabi's legacy before others and already collected a significant collection of his texts.

3. Kazakhstan, indeed, does not have a center of Eastern studies, but such center can be and should be founded. Preparations to the celebration of the $1100^{\text {th }}$ anniversary of Al-Farabi's firth would be an impetus to establish the center of Eastern studies in Kazakhstan [1, 70 p.].

Akzhan Zhaksybekovich wrote: "after a number of meetings and discussions, the final decision was passed to the All-Union Scientific Council on coordination of Oriental studies, which at that time was headed by academic B.G.Gafurov. Bobodzhan Gafurovich made a decision to hold the $1100^{\text {th }}$ Al-Farabi's anniversary events in Alma-Ata. Al-Farabi's jubilee in Alma-Ata initiated celebrating his jubilee in Iraq and other countries".

In 1972, Akzhan Zhaksybekovich published his article 'The Stars of Culture of Central Asia' in Kuwait, in the Al-Farabi Magazine [3, 142 p.], in which he proved that the book 'Music of the Spheres' by German astronomer Johannes Kepler refers to many facts and data and data from Al-Farabi's tract 'Kitab al-musiki al-kabir' ('The Great Book of Music'). After that, many peer reviews on the article reflected the overall acknowledgement that «Mister al-Mashani was right...». Since then, it has been accepted that al-Mashani discovered the name of great Al-Farabi to the people of Kazakhstan [3, 142 p.].

\section{Succession of Al-Farabi and Abai}

In his tract "Al-Farabi and Abai", al-Mashani investigated both scientific and spiritual linkages between those two prominent characters. Abai surely knew about Al-Farabi. This thought was of the bright interest to the scientist, and he proved his conclusion in his research.

Altayev A.Sh. gives a fascinating logical chain. Descendants of Al-Farabi and Abai call them great thinkers. But if they are great, what make their grandeur and sanctity? If we can understand the greatness of those two people, then why not demonstrate and explore spiritual bonds of the two Kazakh sons? "Al-Farabi was a musician, but we say of him as of a philosopher. Abai was a philosopher, but we call him a poet" 
[8]. A.Mashani pioneered in giving an assessment of the world cognition and spiritual achievements of the two outstanding thinkers. For instance, according to A.Mashani's train of thought, if Al-Farabi warns: "The greatness of a scholar is in his perception of the God's path", Abai, by saying "God is the master of decorating the Earth", worships the Master of the world. Or, if Al-Farabi states: "Everyone has his own place in this world', Abai adds: "You are a little brick in the wall of the world. Find your place in it". On the other side, in order to understand the structure of the world and find one's place therein, it is necessary to have a sense of 'gakli parasat'; and if you don't have an ability to differentiate, then it would lead to ignorance. Al-Farabi said: "If you look at the world with your 'gakli' sight, the world is magnificent and you are a personality; while if you look at the world with your 'zhakli' sight, the world is a garbage and you are a monkey". To that extent Abai spoke: "Asempaz bolma arnege, onerpaz bolsan, arkalan. Sen de - bir kirpish, duniege ketigin tap ta bar kalan" ("If you are talented, be proud of that. And be a solid brick in the wall to be erected"), thus transforming the worldview into the action. It may be supposed that both great sages believed that the world is a wonderful creation, and each thing and each person has a special place therein; but perceiving the truth and finding the proper place become possible only when the truth comes from the world itself, i.e., a statement shared by Al-Farabi and Abai that "a man should learn from nature" was observed and analyzed by Akzhan Mashani only. Possibility of discovering such Abai's statements, as 'true and false' ('gakhliya-nakhiya'), 'science-greatness' (gylym-kudyret'), 'heart's scales - insaf' (zhurek tarazysy-insaf'), 'the life is the truth' ('omirdin ozi - shyndyk'), each of which can serve as inspiration for their detailed description and interpretation, can be considered as a gift of the Universe to Mashani [9]. It can hardly be considered an exaggeration to say that the real outcome of the many-year work at Al-Farabi's scientific legacy lies in its inclusion into the spiritual culture of Kazakhstan as one of its historical sources and integral components. The name of Al-Farabi symbolizes authentic roots and fundamentals of the humanistic culture of the freedom-loving nation of Kazakhs. It has become ingrained into the annals of the Kazakh history and, once revived, is voiced over and over again in university halls and academic conference-rooms, in libraries and mass media studios. The name of Al-Farabi is given to avenues and streets in many cities of Kazakhstan, along with the flagship national university, where the thinker's image is depicted in stone right before its principal building, and also libraries and an academic magazine. At present, it has become possible to work with the authentic sources which contain basics of the Kazakh and Turkic spirituality. Various archeological surveys, monuments of the ancient Turkic written language, as well as a large quantity of Indian, Byzantium, and Chinese source are evidences of the highly developed spiritual culture of Turks.

In his speech at the $90^{\text {th }}$ anniversary of A.Mashanov, Rector of the Kazakh National University named after Al-Farabi, Kupzhasar Naribayevich Naribayev, said to him: "You are loved by the entire Kazakh nation since what you did, having looked into the very depth of history, was truly heroic. You brought our ancestor Al-Farabi's spirit and his writings from the country of Sham to share with the nation who had been already afraid of its own history. You helped publishing Al-Farabi's texts and organizing 
celebration in honor of his $1100^{\text {th }}$ anniversary. You proved that Al-Farabi's birthplace is Kazakhstan. And for all of these, people of Kazakhstan bow their heads before you... "[ $[2,7$ p.]

Speaking of Akzhan Mashanov, Olzhas Omarovich Suleimenov noted that "the core goal of the scholar resided in exploring Al-Farabi's legacy. Each nation has a right to know its best sons. Akzhan Mashanov returned Al-Farabi to Kazakhs, and it is his invaluable merit" [2, 16-17 pp.].

\section{Conclusion}

Persons whose names become legendary during their lives are not of frequent occurrence. Each epoch has its scholars, and yet, becoming a genius is a rare phenomenon in the society. Each genius is preconditioned by his or her time. Besides his genius erudition, Akzhan Zhaksybekuly al-Mashani is known for his selfless patriotism and service to his nation. When living in the Soviet atheistic community, he devoted a half-century of his conscious life to studying and spreading treasures of the rich multi-faceted heritage of Abu Nasr Al-Farabi, a great thinker and a person of the encyclopedic knowledge, having returned his name to his historical homeland. Though the prism of the axiological interpretation of our times, the unique legacy of the medieval sage of the city of Otrar in South Kazakhstan region has a considerable ethical meaning to the spiritual transformation of the whole mankind as well as to the successful progress of Kazakhstan towards democracy and spiritually healthy society. We honor Mashani for his hard work that made Farabi-studies one of the leading spheres of the national science.

His huge contribution into the development of theoretical basics of the mining science, along with his scientific and pedagogical activities, was worthily recognized by our society and Government of Kazakhstan. He was awarded with the Order of Lenin, Order of the Red Banner of Labor, and numerous medals. His name is assigned to the Institute of Natural and Humanitarian Sciences under the Kazakh National Technical University named after K.I.Satpayev, and also to one of Almaty streets.

In 2001, during festivities in honor of Al-Farabi's jubilee in Kazakhstan, the academic, after this death, was honored with Al-Farabi's award with the issuance of respective award certificate No. 1.

According to UNESCO's decision, the year of 2006 was declared as the year of the $100^{\text {th }}$ anniversary of Al-Mashani. Kazpost issued a post mark dedicated to that remarkable date.

It seems unfair to measure the significance of his legacy by counting the number of his monographs, articles, and state awards only. His efforts aimed at restoring the spiritual heritage of our people go far beyond the frames of science as they have enduring value for the entire humanity.

\section{List of references}

1 Центральный государственный архив Республики Казахстан. - Дело: По следам Аль-Фараби. - Ф.2285.- Оп.1. - Д. 8. 
2 Машанов А. Өнегелі өмір // ред. басқ. Ғ.М. Мұтанов. - Алматы: Қазақ университеті, 2017. - 312 б.

3 Нурпеисова М.Б. Машановтың ғылыми мектебі. - Алматы: Искандер, 2016. - 223 б.

4 Дукенбаева 3.О., Талгатбек М.М., Шабамбаева А.Г. Ақжанәл-Машани. - Көкшетау, 2019. - 412 б.

5 Центральный государственный архив Республики Казахстан. - Дело: Памятные вехи моего пути в науку. - Ф.2285. - Оп.1. - Д. 76.

6 Научный архив РГП на ПХВ: Ғылым ордасы. - Дело: Программа: Научное наследие Аль-Фараби. - Ф.98. - Оп.1. - Д. 246.

7 Машани А. Аль-Фараби и современная наука. - Алматы, 2007. - 220 с.

8 Алтаев А.Ш. Аль-Машани - выдающийся казахский ученый, писатель, педагог [Электронный ресурс]. 2016. URL: https://articlekz.com/article/21485 (дата обращения 05.10.2021).

9 Малахова О. Открывшим первым: об основоположнике казахстанской школы геомеханики Акжане Машанове // Казахстанская правда. - Алматы, 2006. - 2 июня. - С. 4.

\section{Transliteration}

1 Central'nyj gosudarstvennyj arhiv Respubliki Kazahstan. - Delo: Po sledam Al'-Farabi [In the Footsteps of al-Farabi]. - F.2285. - Op.1. - D. 8.

2 Mashanov A. Onegeli omir [Moral Life] // red. bask. G.M. Mutanov. - Almaty: Kazak universiteti, 2017. -312 b.

3 Nurpeisova M.B. Mashanovtyn gylymi mektebi [Mashanov's Scientific School]. - Almaty: Iskander, 2016. $-223 \mathrm{~b}$.

4 Dukenbaeva Z.O., Talgatbek M.M., Shabambaeva A.G. Ақzhanal-Mashani [Akzhanal-Mashani]. - Kщkshetau, 2019. - 412 b.

5 Central'nyj gosudarstvennyj arhiv Respubliki Kazahstan. - Delo: Pamjatnye vehi moego puti v nauku [Memorable Milestones of my Path to Science]. - F.2285.- Op.1. - D. 76.

6 Nauchnyj arhiv RGP na PHV: Gylym ordasy. - Delo: Programma: Nauchnoe nasledie Al'-Farabi [Al-Farabi’s Scientific Heritage]. - F.98. - Op.1. - D. 246.

7 Mashani A. Al'-Farabi i sovremennaja nauka [Al-Farabi and Modern Science]. - Almaty, 2007. - $220 \mathrm{c}$.

8 Altaev A.Sh. Al'-Mashani - vydajushhijsja kazahskij uchenyj, pisatel', pedagog [AlMashani is an Outstanding Kazakh Scientist, Writer, Teacher] [Jelektronnyj resurs]. 2016. URL: https://articlekz.com/article/21485 (data obrashhenija 05.10.2021).

9 Malahova O. Otkryvshim pervym: ob osnovopolozhnike kazahstanskoj shkoly geomehaniki Akzhane Mashanove [The First to Discover: About the Founder of the Kazakh School of Geomechanics Akzhan Mashanov] // Kazahstanskaja pravda. - Almaty, 2006. - 2 ijunja. - C. 4.

\section{Садуов А.Ж., Макулбеков А.Т.}

Аль-Фараби и мировое наследие аль-Фараби в исследованиях А. Ж. Машанова (аль-Машани)

Аннотация. В статье рассматривается вклад доктора геолого-минералогических наук, профессора, члена-корреспондента Академии Наук Казахской ССР, заслуженного деятеля Казахстана Акжана Жаксыбековича Машанова в исследовании научного наследия Абу Насра Мухаммада ибн Мухаммада аль-Фараби. А.Ж. Машанов первым в Казахстане стал изучать научное наследие аль-Фараби. Докладная записка Машанова от 15.11. 1960 г. на 
имя Президента АН КазССР К.И. Сатпаева о необходимости изучения научного наследия аль-Фараби положила начало развитию фарабиеведения в Казахстане.

Акжан Жаксыбекович не только доказал мировому сообществу, что родиной «Второго Учителя» является город Отрар, но и первым нашел захоронение великого предка на кладбище Баб ас-Сагир в Дамаске. Ученый сумел доказать и убедить научное сообщество СССР в необходимости изучения наследия аль-Фараби в Казахстане, на родине гениального мыслителя. Благодаря ему в 1975 году в Алма-Ате прошла международная научная конференция, посвященная 1100-летию аль-Фараби.

Ключевые слова: А.Ж. Машанов, Абу Наср Мухаммад ибн Мухаммад аль-Фараби, фарабиеведение, Отрар, кладбище Баб ас-Сагир, Китаб аль-Мусики аль-Кабир.

Садуов А.Ж., Мақұлбеков А.Т.

\section{А.Ж. Машанов (әл-Машани) зерттеулеріндегі әл-Фараби және оның әлемдік мұрасы}

Аңдатnа. Мақалада геология-минералогия ғылымдарының докторы, профессор, Қазақ КСР Ғылым Академиясының корреспондент-мүшесі, Қазақстанның еңбек сіңірген қайраткері Ақжан Жақсыбекұлы Машановтың Әбу Насыр Мұхаммед ибн Мұхаммед әл-Фарабидің философиялық-ғылыми мұрасын зерттеудегі үлесі қарастырылады. А.Ж.Машанов Қазақстанда бірінші болып Әл-Фарабидің философиялық-ғылыми мұрасын зерттей бастады. Машановтың 15.11. 1960 ж. ҚазССР ҒА Президенті Қ.И. Сәтбаевтың атына Әл-Фарабидің философиялық-ғылыми мұрасын зерттеу қажеттілігі туралы Қазақстанда Фарабитанудың дамуына негіз болды.

Ақжан Жақсыбекұлы әлемдік қоғамдастыққа «екінші ұстаздың» отаны Отырар қаласы екендігін дәлелдеп қана қоймай, Ұлы бабаның Дамаскідегі Баб ас-Сағыр зиратына жерленуін бірінші болып тапты. Ғалым КСРО-ның ғылыми қоғамдастығын данышпан ойшылдың Отаны-Қазақстанда әл-Фарабидің мұрасын зерттеу қажеттілігін дәлелдеп, сендіре алды. Оның арқасында 1975 жылы Алматыда Әл-Фарабидің 1100 жылдығына арналған халықаралық ғылыми конференция өтті.

Tүйін сөздер: А.Ж. Машанов, Әбу Наср Мұхаммед ибн Мұхаммед Әл-Фараби, Фарабитану, Отырар, Баб әс-Сағир қорымы, Китаб әл-Мусики әл-Кабир. 